\title{
Na czym polega ,lingwistyczna inteligencja” współczesnych syste- mów glottodydaktycznych? Adaptywność w skali mikro- i makro w obecnych rozwiązaniach e-learningowych.
}

\author{
What is "linguistic intelligence" of modern glottodactic systems? Adaptivity on micro- and mac- \\ ro scale in current e-learning solutions.
}

\author{
Pawel SZERSZEŃ \\ Uniwersytet Warszawski/ University of Warsaw \\ E-mail: pszerszen@uw.edu.pl
}

\begin{abstract}
The rapid development of electronic media has resulted in the addition of "closed" and "opened" e-learning solutions using new communication techniques or advanced language analysis system. The purpose of the speech is to try to answer the question what is the so-called "linguistic intelligence" of modern glottodactic systems. The scope of conceptualization of adaptivity (micro and macro scale) and examples of micro- and macro-mobile systems as well as glottodactic systems will be approximated, which due to the complexity of the analysis of linguistic data can be classified as "intelligent" tools.
\end{abstract}

Keywords: linguistic intelligence, artificial intelligence, adaptivity, adaptability, electronic media, analysis of linguistic data, teaching of specialized languages

\section{Wstęp}

Odkąd pojawiły się pierwsze rozważania nad sztuczną inteligencją, zaczęto stopniowo podejmować wysiłki w celu jej wykorzystania w procesie uczenia się. Ich wyrazem stały się m. in. badania sztucznych systemów poznawczych, urządzeń elektronicznych służących do przetwarzania danych oraz wspomagania naturalnych procesów poznawczych w ramach kognitywistyki.

Szybki rozwój technologii informacyjnych i komunikacyjnych oraz towarzyszący mu rozkwit mediów elektronicznych w ostatnich latach sprawił, że obok ,zamkniętych" rozwiązań e-learningowych, udostępnianych np. na płytach CD i DVD, pojawiły się także te „otwarte”, wykorzystujące m.in. nowe techniki komunikowania się czy zaawansowane systemy analizy danych językowych. Wraz z nowymi rozwiązaniami na nowo odżyła refleksja nad możliwością wykorzystania ,inteligentnych"1 systemów w edukacji, w tym w uczeniu (się) języków obcych. Od pewnego

\footnotetext{
${ }^{1}$ Obok tzw. oprogramowania inteligentnego zwykło się dzisiaj mówić także o wielu innych inteligentnych obiektach czy narzędziach, np. zegarkach, samochodach itd. Użycie wyrażenia ,inteligentny" w odniesieniu do zdecydowanej większości używanych przez nas przedmiotów/ obiektów nie znajduje logicznego uzasadnienia (poza użytecznością marketingową),
} 
czasu zaczęto także zastanawiać się nad tym, czy i na ile są one w stanie dostosowywać się do indywidualnych potrzeb ucznia.

Celem niniejszego artykułu jest próba odpowiedzi na pytanie, co jest wyznacznikiem ,lingwistycznej inteligencji” współczesnych systemów glottodydaktycznych. W związku z tym przybliżono zakres pojęciowy wyrażenia adaptywność ${ }^{2}$ oraz podano przykłady systemów mikro- i makroadaptywnych, a także innych systemów glottodydaktycznych, które ze względu na kompleksowość analizy danych językowych można określić mianem narzędzi ,inteligentnych”.

\section{1. „Lingwistyczna inteligencja” a ,sztuczna inteligencja”}

Mówiąc o „lingwistycznej inteligencji”, którą zwykło się przypisywać współczesnym zaawansowanym technologicznie rozwiązaniom e-learningowym (zob. np. projekt LISTiG i inne, por. P. Szerszeń 2014: 176, 182) należy odwołać się najpierw do teorii sztucznej inteligencji. Według Z. Vetulaniego (2004: 23, 54), zadaniem tej ostatniej jest komputerowe modelowanie zwłaszcza tych funkcji czy przejawów aktywności myślowej człowieka, których realizacja angażuje wyższe czynności centralnego układu nerwowego. Należy do nich także modelowanie kompetencji językowej. Dwiema podstawowymi dziedzinami zajmującymi się ,inteligentnym” oprogramowaniem są oparta na postrzeganiu procesów zachodzących w mózgu ludzkim jako systemu operującemu symbolami i działającemu zgodnie z pewnymi regułami tzw. „dobra staromodna sztuczna inteligencja” (GOFAI Good OldFashioned Artifical Intelligence) oraz podejście koneksjonistyczne czy konektywistyczne $^{3}$ (zob. także M. Lister i in. 2009: 626, 633; szerzej na ten temat P. Szerszeń 2014: 50).

Obok rozważań nad sztuczną inteligencją pojawiły się także próby odnoszenia jej do inteligencji człowieka. Porównania obu rodzajów inteligencji, jak również wszelkie przejawy zrównywania sztucznej inteligencji z inteligencją człowieka, zwłaszcza biorąc pod uwage jej wymiar jakościowy, wydają się być w chwili obecnej przedwczesne, wobec czego obarczone są błędem. Inaczej mówiąc: podczas gdy człowiek dzięki swojemu wyposażeniu jest istotą w pełni inteligentną, systemy e-learningowe są w stanie ową inteligencję jedynie w pewnym (nadal dość niewielkim) stopniu obrazować czy naśladować. W zasadzie mogą one być jedynie na tyle

gdyż działanie ww. produktów jedynie w niewielkim stopniu przypomina funkcjonowanie inteligencji ludzkiej. W związku z tym określenie ,inteligentny” w odniesieniu do systemów e-learningowych używane jest przeze mnie w cudzysłowie.

${ }^{2}$ Wyrażenie adaptywność (niekiedy także synonimicznie ,adaptatywność”) jest neologizmem i oznacza tu „zdolność dostosowania się do potrzeb ucznia” w odniesieniu do ,inteligentnych środowisk e-learningowych".

${ }^{3} \mathrm{~W}$ przeciwieństwie do koneksjonizmu, którego zadaniem jest badanie struktury połączeń nerwowych w mózgu, zwolennicy konektywizmu koncentrują się na zewnętrznych związkach i połączeniach, zgodnie z czym uczenie się polega na łączeniu się z ludźmi, będącymi źródłem wiedzy. Zadaniem konektywistów jest próba odtworzenia złożoności budowy mózgu przy użyciu sztucznych form (por. np. założenie, że każdy procesor działa raczej jak pojedyncza komórka nerwowa niż jak mózg, zob. M. Lister i in. 2009: 626). 
,inteligentne”, na ile pozwala aktualny rozwój sztucznej inteligencji (por. M. Lister i in. 2009: 80).

\section{2. „Lingwistyczna inteligencja” maszyn a uczenie języka}

Odwoływanie się do teorii sztucznej inteligencji czy mówienie o ,lingwistycznej inteligencji” maszyn w kontekście kształtowania umiejętności ucznia nie jest przypadkowe także z innych względów. Postrzeganie samego procesu uczenia się jako przetwarzanie informacji znacznie zbliżyło jego główne założenia do założeń teorii sztucznej inteligencji, czego owocem stały się próby tworzenia m.in. ,inteligentnych" systemów tutorialnych bądź adaptywnych środowisk uczenia się. Pojawienie się pierwszych prototypów tego typu oprogramowania spotkało się jednak z krytyką pedagogów i psychologów uczenia się. Jej ostrze zwrócone zostało w kierunku niewspółmiernie wysokiego nakładu pracy przy tworzeniu programów w porównaniu z uzyskiwanymi efektami uczenia (por. K. J. Klauer/ D. Leutner 2007: 307, P. Arnold et al. 2011: 103). Mimo głosów krytyki, twórcy współczesnych środowisk e-learningowych, podnoszą m.in. takie kognitywistyczne hasła jak np. odkrywcze, kierowane ciekawością i samosterowalne uczenie się, eksplorowanie, samodzielne poszukiwanie i porządkowanie informacji w celu znalezienia rozwiązania problemu. Hasła te, w zetknięciu ze wspieranym komputerowo uczeniem się, skutkują m.in. kreowaniem coraz bogatszych środowisk uczenia się, wykorzystujących otwarte ścieżki działania, symulacje i hipermedia, a także refleksją nad koniecznością rozwijania metawiedzy uczących się dotyczącej własnych celów i dróg uczenia się (por. A. Blumenstengel 1998 za P. Arnold et al. 2011: 103).

Niezależnie od tych tendencji należy jednak wyrazić pogląd, że oprogramowanie dydaktyczne obecnej generacji, pomimo bazowania w coraz większym stopniu na sztucznej inteligencji, w dalszym ciągu nie jest w stanie zaplanować i w pełni nadzorować szeroko pojmowanego procesu dydaktycznego, z uwzględnieniem jego wszystkich etapów. Obok tych istotnych ograniczeń posiada ono jednak także mocne strony, które odnoszą się do niektórych działań organizacyjnych i zarządzających, a także tych mających na celu prezentację zróżnicowanych materiałów dydaktycznych. Główne zalety ww. oprogramowania dotyczą przede wszystkim: (a) równoczesnego wykonywania (tych samych lub różnych) zadań dydaktycznych przez wiele osób oraz dokonywania szybkiej oceny (niektórych typów) ww. zadań; (b) jednoczesnego nadzorowania pracy wielu osób uczących się; (c) stałego dostępu do korzystania z oprogramowania dydaktycznego; (d) precyzyjnego nadzorowania realizowanego przez uczniów curriculum dydaktycznego; (e) integracji wielu różnych materiałów glottodydaktycznych; (f) możliwości kolaboracji (np. w obrębie uczestników grup projektowych czy wspólnot e-learningowych); (g) możliwości tworzenia przestrzeni w sieci sprzyjającej rozwijaniu indywidualnych zainteresowań uczniów; (h) możliwości większego wpływu uczniów na przebieg i treści nauczania; (i) możliwości tworzenia własnego ,warsztatu pracy” dla przygotowujących się do zajęć nauczycieli etc. (por. P. Szerszeń 2014: 178 i nast.). 


\section{3. „Lingwistyczna inteligencja” jako adaptywność/ adaptowalność współcze- snych środowisk uczenia i jej granice}

Powracając do kwestii ,inteligencji” współczesnych rozwiązań e-learningowych, można ją rozpatrywać na płaszczyźnie adaptywności, czyli możliwości dopasowywania się bądź adaptowalności, czyli możliwości dopasowania (adaptacji, ang. adaptivity, niem. Adaption/ Adaptation, por. D. Burgos et al. 2007) do potrzeb uczących się bądź do potrzeb wynikających z sytuacji uczenia (por. H. Niegemann ${ }^{4}$, zob. także H. Mitschian 2010: 26).

Pod pojęciem adaptacji rozumiane są tutaj wszystkie aspekty personalizacji środowisk uczenia, której bieguny wyznaczają wspomniane wyżej adaptywność oraz adaptowalność (ang. adeptability, niem. Adaptivität). Tej ostatniej, która oznacza przebiegający w sposób świadomy i autonomiczny proces dopasowywania środowiska uczenia przez jego użytkownika, przeciwstawiana jest adaptywność, która kierowana jest co do formy w pełni przez środowisko uczenia ${ }^{5}$. Systemy adaptywne w rzeczywistości nie mogą jednak być przyporządkowane żadnemu z podanych ekstremów, gdyż wykazują różne przejawy obydwu form adaptacji (D. Burgos et al. 2007).

Ponadto wyróżnić można różne źródła inputu informacyjnego, w tym obserwację interakcji użytkownika ze środowiskiem uczenia (np. platformą), wcześniej określone reguły sterowania adaptacją oraz przeciwstawione tym działaniom i świadome decyzje ucznia bądź nauczyciela dotyczące sterowania (D. Burgos et al. 2007).

Niekiedy adaptywność bywa rozpatrywana także w skali mikro- i makro ${ }^{6}$. I tak środowisko uczenia/ narzędzie można określić mianem mikroadaptywnego, gdy jest ono w stanie ,samodzielnie" określić zakres wsparcia ucznia i dostosowania się do jego aktualnych potrzeb (por. D. Leutner 2002). W związku z tym wykorzystywany jest tu taki model ucznia, który w oparciu o bieżącą interakcję (uczeń-narzędzie/ środowisko uczenia) podlega modyfikacji w trakcie kursu. W modelu tym uwzględnia się takie właściwości ucznia, jak motywacja, dotychczasowa wiedza czy styl uczenia się. W związku z tym wprowadzane są różne formy modyfikacji środowiska uczenia się, do których Brusilovsky (1998) zalicza:

\footnotetext{
${ }^{4}$ Do wniosku tego doszedłem w roku 2015, m.in. w rozmowach z prof. H. Niegemannem, jednym z najbardziej znanych niemieckich badaczy multimediów, zob. H. Niegemann i in. 2008. W dalszej części artykułu będę odnosił się głównie do bardziej zaawansowanej formy adaptacji systemów e-learningowych czyli adaptywności.

${ }^{5}$ Podział środowisk uczenia na adaptywne i adaptowalne ma charakter upraszczający, gdyż nie tylko te drugie, ale także pierwsze nie są w pełni autonomiczne, lecz oparte o działania programistyczne osób z zewnątrz.

${ }^{6}$ Poniższe uwagi na temat mikro- i makroadaptywnósci pochodzą z monografii R. Lehmanna (2010: 17 i nast.)

${ }^{7}$ Wyrażenie „samodzielnie” nie oznacza tu w pełni samoistnej ingerencji systemu, gdyż jest on tworem programowalnym, tzn. że jego reakcje są z góry ustalone w przypadku zaistnienia określonych (i przewidzianych przez nauczyciela i/ lub programistę) warunków.
} 
- sekwencjonowanie materiału dydaktycznego: o porządku jednostek dydaktycznych (modułów) decyduje uczeń, który sam rozstrzyga o kolejności poszczególnych tematów (tzw. sekwencjonowanie wyższego poziomu) bądź kolejności poszczególnych elementów danego obszaru tematycznego (tzw. sekwencjonowanie niższego poziomu);

- inteligentną analizę wyników pracy: kolejna jednostka dydaktyczna proponowana jest w oparciu o zanalizowane wyników testu, któremu poddany został uczeń;

- interaktywne wsparcie przy rozwiązywaniu problemów: W trakcie pracy nad zadaniem uczeń otrzymuje pomoc w oparciu o analizę dotychczasowych prób rozwiązania zadania;

- adaptywną prezentację: prezentacja treści kształcenia dostosowywana jest bezpośrednio do potrzeb ucznia;

- adaptywne wsparcie kooperacji: do zadań wspólnych członkowie grupy roboczej dobierani są na podstawie analizy ich profili tak, aby osiągnąć jak najbardziej efektywne wyniki;

- adaptywną nawigację: elementy nawigacyjne środowiska uczenia dostosowywane są do potrzeb uczestników.

Niezależnie od ww. możliwości modyfikacji nie udało się jednak dotychczas skonstruować takiego środowisko uczenia, które w oparciu o model ucznia, uwzględniający jego motywację, styl uczenia się czy dotychczasową i zdobytą w trakcie danego kursu wiedzę itp. elementy byłoby w stanie wykorzystać wszystkie możliwości modyfikacji materiału. W większości operacjonalizacji podlegają zaledwie jedna bądź dwie zmienne w modelu ucznia i przeprowadzane są jedna lub dwie modyfikacje (zob. R. Lehmann 2010: 17-18).

W przeciwieństwie do systemów mikroadaptywnych, które zdane są na pracochłonne rozwiązania techniczne, systemy makroadaptywne dostosowywane są do potrzeb uczniów przez nauczycieli, przy czym najczęściej zakładają one jedynie jednorazową interwencję tych ostatnich na początku kursu. Tym samym systemy makroadaptywne wyróżniają niższe koszty techniczne, które należy ponieść jedynie na starcie. Pośrednio wykorzystywany jest tutaj także model ucznia, zakładający większą swobodę, gdyż nie musi on być modyfikowany przez komputer. Konieczne jest jednak w tym przypadku przy opisie ucznia zbadanie takiego aspektu, który pomiędzy okresami interwencji nie ulegnie zmianie (por. R. Lehmann 2010: 18).

Oprócz adaptywności w skali makro- i mikro, w literaturze przedmiotu obecne są także inne jej modele, uwzględniające m. in. podział obiektów adaptacyjnych czy cel uczenia. I tak w modelu D. Burgosa obiekty adaptacyjne można podzielić na trzy grupy: w pierwszej grupie personalizowane są przebieg procesu uczenia (układ treści), forma treści nauczania oraz interfejs użytkownika, w drugiej zaś adaptacja obliczona jest na wsparcie przy rozwiązywaniu problemów i planowanie składu grup uczących się, trzecia grupa opisuje adaptację ewaluacji oferty dydaktycznej (zob. D. Burgos et al. 2007).

Kolejnym kryterium, kierujące uwagę w procesach adaptacji na różne środowiska uczenia jest jego cel. D. Leutner (2002) wyróżnia tutaj trzy modele: model 
wspierający, kompensacyjny oraz preferencyjny. W pierwszym z nich zniwelowane powinny zostać deficyty ucznia poprzez dodatkowe jednostki dydaktyczne, przy czym niedobory określane są przez testy bądź ćwiczenia sprawdzające. W modelu kompensacyjnym podejmowana jest próba wyrównania stwierdzonych przez ucznia niedociągnięć dotyczących założeń procesu uczenia poprzez wprowadzenie odpowiedniego systemu pomocy. W modelu preferencyjnym nie identyfikuje się ani nie równoważy żadnych deficytów ucznia, lecz optymalnie wykorzystuje mocne strony ucznia.

Jak widać różne modele kategoryzacji adaptywnych środowisk uczenia wykazują wprawdzie pewne podobieństwa, jednak jedynie poprzez integrację różnych modeli są w stanie stworzyć pełniejszy obraz adaptacji środowisk uczenia (zob. kompleksowy trzystopniowy jej model, D. Burgos/ C. Tattersall/ R. Koper 2007, schemat 1).

Na podstawie tych modeli można wyróżnić pięć wymiarów (determinant) adaptacji środowisk uczenia: (1) jednostka przeprowadzająca (podmiot); (2) źródło inputu decyzyjnego (input); (3) taktowanie adaptacji (taktowanie); (4) przedmiot adaptacji (przedmiot); (5) cel adaptacji (cel). Punkty 1, 2 i 4 są przystawalne pod względem treści do modelu D. Burgosa (D. Burgos et al. 2007). Punkt trzeci nawiązuje do podziału na mikro- i makroadaptywnośc wg D. Leutnera (2002). Punkt 5 uwzględnia dyferencjację celu adaptacji wg D. Leutnera (tamże.).

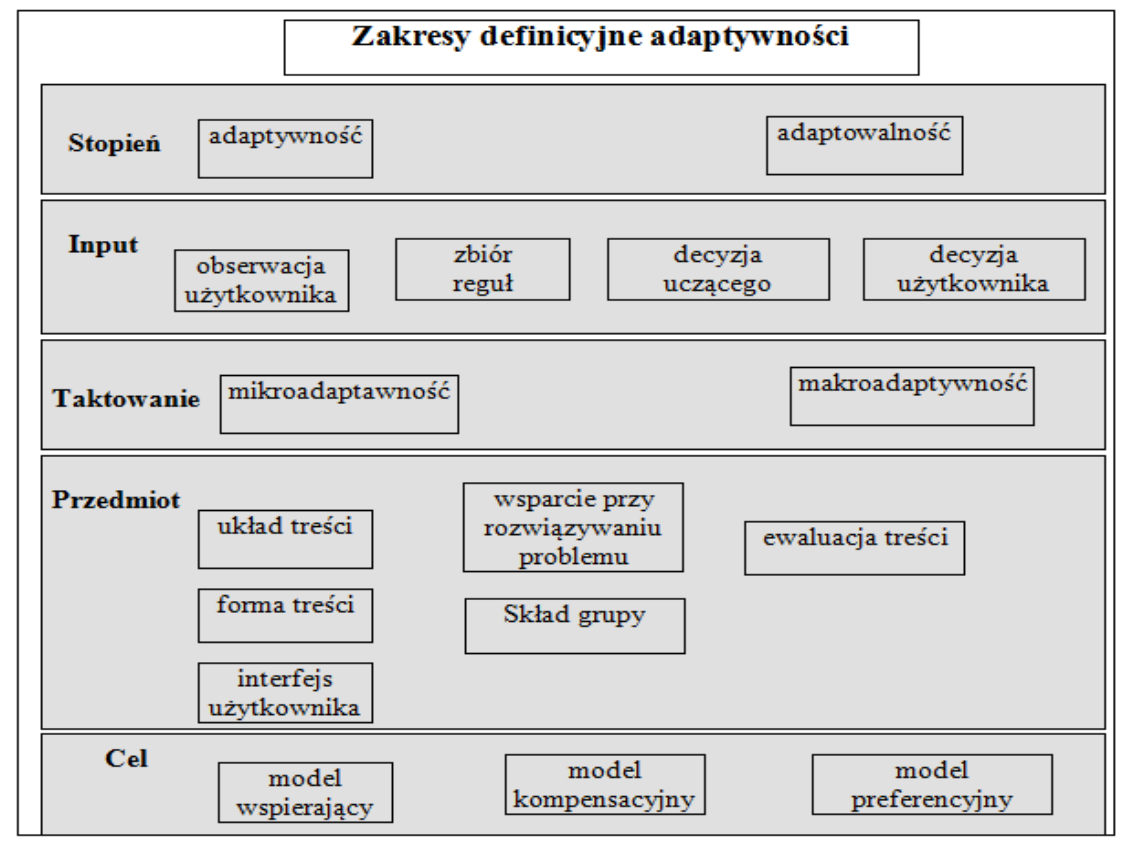

Rys. 1. Zakresy definicyjne adaptywności wg D. Burgosa/ C. Tattersalla/ R. Kopera (2007), thum.: P. Sz.

Podsumowując wypada przyznać rację H. Niegamannowi (2008), że w przypadku mediów elektronicznych, adaptywność stanowi istotny przymiot systemów inte- 
raktywnych. Polega ona na odpowiednim (adekwatnym) reagowaniu systemu (w postaci konkretnego komunikatu), które powinno odnosić się do wprowadzonego uprzednio przez jego użytkownika komunikatu i, w miarę możliwości, uwzględniać specyfikę ucznia (np. jego aktualny stan wiedzy, zainteresowania). Innymi słowy, o stopniu adaptywności danego środowiska uczenia (np. interaktywnego systemu), świadczy poziom dostosowywania jego reakcji do zmieniających się warunków uczenia, w szczególności do aktualnych potrzeb uczniów, wynikających z indywidualnych uwarunkowań procesu uczenia, w tym obecnie osiąganych postępów. Owo dostosowanie się powinno uwzględniać różnice pomiędzy uczniami, a także, zdaniem D. Leutnera 2002, odnosić się zwłaszcza do: zakresu instrukcji, czasu uczenia się, sekwencyjności, czasu prezentacji zadania bądź stopnia jego trudności.

Jak pokazała praktyka tworzenia adaptywnych środowisk uczenia, ich efektywność związana jest ze stopniem przezwyciężania trudności wynikających z konieczności wykorzystania przy ich konstruowaniu obszernej wiedzy na temat wzajemnych zależności pomiędzy indywidualnymi cechami uczniów i cechami danych środowisk uczenia (por. D. Leutner 2002, 2008). I choć ww. pierwsze próby tworzenia „inteligentnego" oprogramowania nie przyniosły pożądanych skutków, po okresie pewnej stagnacji w zakresie badań nad adaptywnymi systemami uczenia problem adaptywności stopniowo powraca (por. np. V. Shute/ B. Towle, 2003), co jest dowodem na to, że w istocie stanowi on centralny aspekt współczesnego e-learningu. W sytuacji, w której nie ma przekonania co do możliwości samodzielnych działań uczniów w zakresie uzyskania i odpowiedniego przygotowania materiałów nauczania czy choćby rozwijania nabytych umiejętności, systemy e-learningowe stają się stopniowo środowiskiem udostępniania oferty dydaktycznej dopasowującej się i/ lub dopasowywanej do indywidualnych potrzeb ucznia.

Jeśli chodzi o tzw. adaptywny e-learning, który wyszedł poza ramy laboratoryjne, to jak dotąd nie ma jednak zbyt wielu przykładów jego efektywnego zastosowania $^{8}$.

\section{Adaptywność w praktyce glottodydaktycznej. Przyklady ,inteligentnych” systemów e-learningowych}

Adaptywność w praktyce glottodydaktycznej napotyka na dość istotne ograniczenia. Wyrazem tego jest m.in. proponowany $\mathrm{w}$ większości e-learningowych środowisk uczenia dość ogólny podział na początkujących, średnio zaawansowanych i zaawansowanych, który często nie uwzględnia rzeczywistych potrzeb ucznia i skutkuje m.in. brakiem elastyczności w zakresie doboru, wykorzystywania i/ lub modyfikacji materiałów nauczania, z czego wynika najczęściej konieczność dostosowania się do

\footnotetext{
${ }^{8}$ por. LearningBrands.com.zob. URL http://216.247.191.87/clients/LBR/site/solutions/alearn ing.htm). [pobrano 20.042017]; AdaptiveTutoring.com,(zob.URLhttp://www.adaptivetutorin g.com/; Learning Machines Inc. zob. URL http://www.learningmachines.com) (H.M. Niegemann 2008: 308).
} 
skostniałych ram jednostek lekcyjnych. H. Mitschian zwraca ponadto uwagę na dość wąskie granice adaptywności w tzw. mikrouczeniu się (H. Mitschian 2010: 20), w którym w zasadzie najczęściej mamy do czynienia z analizą komunikatów ucznia opartą o dość ograniczone rozwiązania softwarowe (por. H. Mitschian 2010: 26, 86).

Systemy adaptywne wykorzystywane są m.in. w nauce słownictwa. I choć większość $\mathrm{z}$ nich nie wykorzystuje $\mathrm{w}$ pełni dostępnych opcji (zob. H. Mitschian 2010: 86), to istnieją jednak pewne wyjątki, jak np. system iVocabulary Ch. Beera, który uwzględnia udział we wspólnym projekcie podmiotów z zewnątrz, np. w postaci producentów materiałów dydaktycznych, jak również umożliwia rozszerzanie baz słownictwa.

Systemy do nauki słownictwa dostępne są także coraz powszechniej na smartphonach, choć nie wszystkie z nich są w stanie sprostać potrzebom ucznia, tj. dające się modyfikować (adaptować) czy uzupełniać o nowe wpisy. Większość z nich narzuca konkretne treści, wobec czego ogranicza możliwości dopasowywania się do indywidualnych potrzeb ucznia czy wykonywanych przez niego aktualnie działań. O ile w przypadku uczniów początkujących nie musi stanowić to większego problemu (w przypadku oferty słownictwa zgodnej ze słownictwem nabywanym na poziomie podstawowym), o tyle w przypadku uczniów bardziej zaawansowanych może oznaczać to istotną barierę $\mathrm{w}$ ich efektywnym wykorzystywaniu (por. H. Mitschian: 2010: 140, 158 i nast.).

Wzrostu adaptywności ww. systemów należy wobec tego oczekiwać poprzez poszerzanie/ rozbudowywanie ich o opcje wprowadzania własnych wpisów i modyfikacji ich (w każdej chwili) przez osoby uczące się, co spowoduje, że będą one mogły być wykorzystywane przez cały proces uczenia się. Zbiory słownictwa powinny zatem $\mathrm{w}$ większym stopniu odpowiadać indywidualnym potrzebom uczniów na danym etapie nauczania i niejako rozwijać się (ewaluować) wraz z rozwojem umiejętności ucznia.

I choć brakuje na razie podstaw teoretycznych tworzenia tego typu materiałów ${ }^{9}$, to, zdaniem niektórych badaczy, zob. np. H. Mitschian (2010: 159), dostępne są wyniki badań nad tworzeniem oferty dydaktycznej z dziedzin pokrewnych, które z powodzeniem można przenieść na grunt dydaktyki języków obcych. Z pomocą mogą przyjść tutaj także próby tworzenia adaptywnych systemów wspierających naukę słownictwa, a także portale oferujące adaptowalne materiały nauczania.

Wśród najbardziej zaawansowanych technologicznie aplikacji internetowych wymienić należy ,inteligentne” systemy tutorialne (IST) wykorzystujące tzw. pedagogicznych agentów (PA) ${ }^{10}$. Zadaniem tych ostatnich jest przede wszystkim właści-

${ }^{9}$ R. Lehmann 2010, zwraca uwagę na konieczność refleksji nad stylami uczenia się jako podstawy dalszych badań nad adaptywnością systemów e-learningowych.

${ }^{10}$ Obok tych najbardziej zaawansowanych aplikacji internetowych należy wspomnieć o ww. systemach ułatwiających zapamiętywanie słownictwa, stosowanych także w tzw. edukacji mobilnej, por. np. serwisy internetowe, www.babbel.com, www.quizlet.com, www. memrise.com., www.duolingo.com, www.fiszki.pl, czy www.fiszkoteka.pl. Ww. oprogramowanie pozwala m.in. tworzyć tradycyjne fiszki, wzbogacone o nagrania słów/wyrażeń, ilustracje, oferuje także niekiedy tzw. „system długotrwałej nauki”, pozwalający na efektywne powtór- 
we reagowanie na preferencje użytkowników, klasyfikowanie informacji i rozwiązywanie różnych problemów ucznia na podstawie zgromadzonych doświadczeń. Wizualizacją pedagogicznego agenta jest najczęściej ludzka postać (np. animowana figura 3D lub awatar), a jego działanie przypomina zachowanie człowieka. Pedagogiczni agenci wykorzystują do komunikowania się teksty mówione i mogą występować w roli trenera, doradcy, eksperta czy osoby zadającej pytania bądź po prostu towarzyszącej procesowi uczenia się (zob. O. Bendel, 2003, A. RokickaBroniatowska, 2004).

$\mathrm{Na}$ szczególną uwagę zasługują takie ,inteligentne" systemy tutorialne (IST), które są programami mikroadaptywnymi, dopasowującymi się do właściwości użytkownika, tj. np. do zakresu posiadanej przez niego wiedzy, sposobu/ sposobów działania czy poszukiwania informacji i będącymi w stanie w zależności od potrzeb i oczekiwań udzielić pomocy w procesie uczenia (np. poprzez ofertę odpowiednio dopasowanych ćwiczeń). Ich zadaniem jest samodzielne ustalenie zakresu pomocy (por np. takie systemy, jak Tell Me More Campus, a także przykład jednego z najbardziej zaawansowanych systemów do nauki języków obcych o nazwie ALELO, wykorzystującego m.in. bogatą ofertę gier i symulacji, pedagogicznych agentów ${ }^{11}$.

Istnieje także oprogramowanie łączące cechy rozwiązań systemów mikroadaptywnych z rozwiązaniami systemów makroadaptywnych (wymagających mniejszego nakładu pracy twórców), które dopasowują środowisko uczenia przy udziale nauczyciela itd. (zob. D. Leutner 2002, R. Lehmann 2010).

Przykładem jednego z nich jest ww. oprogramowanie Tell Me More Campus (TMM Campus), które powstało na bazie znanego od dość dawna i udostępnianego przede wszystkim na płytach CD-ROM, programu Tell me more. Cechuje je przyjazny dla użytkownika intuicyjny interfejs, zaś przeznaczone ono jest do nauki języków obcych (w tym angielskiego, niemieckiego, francuskiego, hiszpańskiego, włoskiego, niderlandzkiego, w wersji zamkniętej na płytach CD-ROM także innych języków jak chiński, japoński czy arabski), zarówno w zakresie języka podstawowego, jak i specjalistycznego na różnych poziomach (od A1 do C1). Można z nim pracować zarówno samodzielnie, realizując kolejne etapy wybranej przez siebie modułowej ścieżki edukacyjnej, jak również w połączeniu z programem nauczania bądź w ramach kształcenia uzupełniającego (zajęć dodatkowych).

Do ,inteligentnych” rozwiązań wykorzystanych w programie zaliczyć należy m.in. zaawansowany (choć nie zawsze bez zarzutu działający) system rozpoznawania mowy (Spoken Error Tracking System), na którym opierają się ćwiczenia wymowy, a także rozmowę wirtualną. W ostatnim przypadku producent oprogramowania reklamuje ją jako dość swobodną rozmowę z rodzimym użytkownikiem języka (w amerykańskiej odmianie języka angielskiego). Przeprowadzone (przez autora

ki. Wśród zgłaszanych uwag krytycznych pod adresem wymienionej metody zapamiętywania słownictwa wymienić należy fakt, że w procesie tworzenia fiszek uczestniczy ,sam program", podczas gdy podczas klasycznego zapisywania słownictwa to uczeń zapisuje je własnoręcznie, co w większym stopniu wspiera zapamiętywanie.

${ }^{11}$ Zob. http://www.alelo.com/alelo_inc_rt_its.html [pobrano 13.02.2017]. 
pracy samodzielnie i z udziałem uczniów) testy próbne ww. funkcji wykazały, że jest to w zasadzie realne, lecz jedynie w ściśle ograniczonym zakresie, tj. zredukowanym do określonego tematu i używania pewnych wcześniej podanych fraz, wyrazów etc. Niemniej jednak należy podkreślić, że program oferuje nowy ciekawy typ ćwiczenia, który wart jest dalszych prac rozwojowych i może być stosowany zwłaszcza w kontekście uczenia języków specjalistycznych (np. podczas ćwiczenia użycia słownictwa specjalistycznego w konkretnej sytuacji komunikacyjnej).

$\mathrm{Na}$ uwagę zasługują także takie funkcje, jak: narzędzia autorskie do tworzenia materiałów interaktywnych na podstawie przygotowanych przez siebie tekstów; śledzenie postępów uczenia się i inne (szerzej na ten temat P. Szerszeń 2014).

Innym programem, na który warto zwrócić uwagę, jest makroadaptywny system LISTiG, wykorzystywany w dydaktyce tłumaczenia oraz dydaktyce języków specjalistycznych (przede wszystkim w zakresie rozwijania umiejętności gramatycznych i leksykalnych). Novum w przypadku tego systemu jest automatyczna ocena wypowiedzi wytworzonych przez uczących się, która przebiega zarówno na płaszczyźnie czysto lingwistycznej, jak i na płaszczyźnie translatorycznej. Ocena taka jest generowana przez system w formie metakomunikatów zwrotnych, tj. komunikatów, które nie tylko informują o poprawnym lub niepoprawnym rozwiązaniu zadania, ale także, w przypadku niepoprawnego rozwiązania zadania, o rodzaju popełnionego błędu. Generowanie metakomunikatów jest możliwe przede wszystkim dzięki zaimplementowaniu do programu modułów analizy gramatycznej i ortograficznej oraz analizy morfosyntaktycznej i semantycznej (o budowie, działaniu i wstępnej ewaluacji oprogramowania LISTiG zob. więcej w P. Szerszeń 2014).

\section{Podsumowanie}

Podsumowując powyższe rozważania, należy zauważyć, że tzw. „lingwistyczna inteligencja" współczesnych systemów glottodydaktycznych, która rozumiana bywa najczęściej jako adaptywność w skali mikro i makro, nie znajduje zastosowania w większości rozwiązań e-learningowych. Pomimo trwających prac nad ciągłym udoskonalaniem ww. rodzajów oprogramowania, nadal trudno jest obecnie jednoznacznie stwierdzić, czy inteligentne systemy tutorialne włączające pedagogicznych agentów mają istotny wpływ na jakość uczenia (por. I. Fleischer i in. 2008, M. Kerres 1998, P. Arnold i in. 2011; R. Lehmann 2010) W związku z tym, można nadal za M. Kerresem (1998) powtarzać, że wizja ,inteligentnego oprogramowania” narzucającego rozwiązania wydaje się być ciągle iluzoryczna, wobec czego należy tworzyć takie oprogramowanie, które byłoby w stanie dopasowywać się do potrzeb uczących się (w zakresie prezentacji informacji, doboru formy interakcji, rodzaju nawigacji itp.), a więc w zoptymalizowany sposób prezentować ofertę edukacyjną (R. Schulmeister 2003: 14).

Podejmując próbę udzielenia odpowiedzi na pytanie, na czym polega „lingwistyczna inteligencja" współczesnych systemów glottodydaktycznych w uczeniu się i nauczaniu języków obcych należy stwierdzić, że odnosi się ona przede wszystkim do adaptywności rozumianej jako możliwość dopasowywania się do poziomu aktualnej wiedzy i umiejętności ich użytkowników, proponując w związku z tym wyko- 
nanie odpowiednich ćwiczeń (zob. np. programy e-Tutor czy TMM Campus, który pozwala na ćwiczenie bardziej zaawansowanej interakcji maszyna-człowiek w odniesieniu do różnych kontekstów komunikacji językowej, zwłaszcza specjalistycznej, np. organizowanie spotkań biznesowych, podróży służbowych etc.). Niekiedy znajduje ona wyraz w sposobie analizy wprowadzanych przez użytkownika systemu danych językowych oraz stosowanych metakomunikatów zwrotnych.

Obok zasadności tworzenia systemów pierwszego typu, tj. systemów adaptywnych, (zob. np. D. Leutner, 2002, 2008) oraz doskonalenia systemów opartych na komputerowej analizie morfosyntaktycznej i semantycznej i wykorzystujących metakomunikaty zwrotne (np. oprogramowanie LISTiG), a także ciągłego doskonalenia systemów rozpoznawania mowy (zob. np. Tell me More Campus i in.) nie należy, abstrahując od głównego nurtu rozważań, przy konstruowaniu narzędzi e-learningowych rezygnować $z$ dalszego rozwijania systemów nawiązujących do teorii behawiorystycznych, tj. opartych głównie na zerojedynkowej reprezentacji wiedzy i stawiających sobie za cel wyćwiczenie pewnych nawyków w działaniu komunikacyjnym, jak i tych bazujących na kontakcie z nauczycielem.

„Inteligencji” przyszłych systemów e-learningowych należy z jednej strony upatrywać w oprogramowaniu podobnym do ww. systemów adaptywnych, które dodatkowo byłyby w stanie w większym stopniu uwzględnić istniejącą już i stale uzupełnianą ofertę narzędzi e-learningowych, w tym tych z nich, które oparte są o narzędzia społecznościowe (zob. m.in. M. Kerres et al. 2017). Tym samym rola człowieka, zarówno przy ich projektowaniu, jak i szeroko rozumianej ewaluacji wydaje się być ciągle nieodzowna. Tak rozumiane wykorzystanie wszelkich narzędzi e-learningowych może przyczynić się do szerszego wykorzystania walorów mediów elektronicznych w dydaktyce (języków obcych), tj. ich multimedialności, interaktywności i adaptywności (w skali mikro i makro).

\section{Bibliografia}

Arnold, P./ L. Kilian/ A. Thillosen et al. (2011), Handbuch E-Learning. Lehren und Lernen mit digitalen Medien. Bielefeld.

Brusilovsky, P. (1998), Methods and techniques of adaptive hypermedia (w:) P. Brusilovsky/ A. Kobsa/ J. Vassileva (red.), Adaptive Hypertext and Hypermedia. Dordrecht, 1-43.

Bendel, O. (2003), Pädagogische Agenten im Corporate E-Learning. Dissertation. St. Gallen.

Burgos, D./ C. Tattersall/ R. Koper (2007), How to Represent Adaptation in e-Learning with IMS Learning Design, (w:) "Interactive Learning Environments" 15(2), 161-170.

Kerres, M. (1998), Multimediale und telemediale Lernumgebungen. Konzeption und Entwicklung. München.

Kerres, M/ T. Hölterhof/ M. Rehm (2017), Lebenslanges Lernen im Kontext sozialer Medien: Chancen für formelles und informelles Lernen, (w:) D. Münk/ 
M. Walter (red.), Lebenslanges Lernen im sozialstrukturellen Wandel, Wiesbaden, 141-170.

Klauer, K.J./ D. Leutner (2007), Lehren und Lernen. Einführung in die Instruktionspsychologie. Weinheim/ Basel.

Lehmann, R. (2010), Lernstile als Grundlage adaptiver Lernsysteme in der Softwareschulung. Münster.

Leutner, D. (2002), Adaptivität und Adaptierbarkeit multimedialer Lehr- und Informationssysteme, (w:) L. Issing/ P. Klimsa (red.), Information und Lernen mit Multimedia und Internet. Lehrbuch für Studium und Praxis, Weinheim, 115125.

Leutner, D. (2008), Adaptivität und Adaptierbarkeit beim Online-Lernen, (w:) L.J. Issing/ P. Klimsa (red.), Online-Lernen. Handbuch für Wissenschaft und Praxis. München, 115-124.

Lister, M./ J. Dover/ S. Giddings et al. (2003, 2009), Nowe media. Wprowadzenie, tłum.: M. Lorek/ A. Sadza/ K. Sawicka. Kraków.

Mitschian, H. (2010), M-Learning - die neue Welle. Mobiles Lernen für Deutsch als Fremdsprache. Kassel.

Niegemann, H.M./ S. Domagk/ S. Hessel et al. (2008), Kompendium Multimediales Lernen. Berlin/ Heidelberg.

Rokicka-Broniatowska, A. (2004), Zastosowania technologii agenckich $w$ adaptatywnych webowych systemach uczenia, (w:) ,Roczniki Kolegium Analiz Ekonomicznych" $12,131-153$.

Schulmeister, R., (2003), Lernplattformen für das virtuelle Lernen. Evaluation und Didaktik. München.

Shute, V./ B. Towle (2003), Adaptive E-Learning, (w:) „Educational Psychologist” 38 (2), 105-114.

Szerszeń, P. (2014), Platformy (glotto)dydaktyczne. Ich implementacja w uczeniu specjalistycznych języków obcych, (Studi@ Naukowe 15). Warszawa.

Vetulani, Z. (2004), Komunikacja człowieka z maszyna. Komputerowe modelowanie kompetencji językowej. Warszawa. 